\title{
Uma análise cruzada de três estudos de caso com professores de física: a influência de concepções sobre a natureza da ciência nas práticas didáticas
}

\author{
A cross analysis of three case studies with physics teachers: \\ the influence of the nature of science conceptions \\ in classroom practices
}

Neusa Teresinha Massoni ${ }^{1}$. Marco Antonio Moreira ${ }^{1}$

\begin{abstract}
Resumo: Este estudo investigou possíveis relações entre as concepções sobre a natureza da ciência, de professores de Física, e suas práticas docentes, por meio de uma análise cruzada de três estudos de caso do tipo etnográfico. A observação etnográfica deu-se por imersão nas aulas de Física de três professores de Ensino Médio atuando em diferentes tipos de escolas: particular, pública e militar. Os resultados do cruzamento indicaram: que as práticas didáticas observadas não incluem aspectos sobre a natureza da ciência; que a Epistemologia e a História da Física ainda não se fazem presentes de forma explícita nas aulas de Física do Ensino Médio; que as relações entre as visões epistemológicas dos professores e suas práticas são frágeis e se manifestam de forma implícita. No entanto, foi possível vislumbrar algumas diferenças nas práticas daqueles professores que têm uma visão epistemológica mais contemporânea, pois tendem a manter um espírito mais aberto à inovação didática.
\end{abstract}

Palavras-chave: Natureza da ciência. Didática. Ensino de física. Ensino Médio.

\begin{abstract}
The purpose of this study was to investigate possible relationships between the conceptions about the nature of science held by physics teachers and their classroom practices through a cross analysis of three ethnographical case studies. The ethnographical observation was carried out through immersion in the physics classes of three high school teachers acting in different types of schools: private, public and military. The findings indicated that the observed didactic practices do not include any aspects of the nature of science, and that Epistemology and History of Physics are not yet present in high school physics classes. This study suggests that the relationship between the epistemological views of teachers and their practices are fragile and are manifested implicitly. Nevertheless, it was possible to observe some differences in the practices of those teachers who have a more contemporary epistemological view, and who tend to keep a more open mind to didactic innovation.
\end{abstract}

Keywords: Nature of science. Didactics. Physics teaching. High School.

\footnotetext{
${ }^{1}$ Departamento de Física, Universidade Federal do Rio Grande do Sul (UFRGS), Caixa Postal 15051, CEP 91501-970, Porto Alegre, RS, Brasil. E-mail: <neusa.massoni@ufrgs.br>
} 


\section{Introdução}

Uma linha de pesquisa relativamente comum em Ensino de Física investiga tipos de concepções sobre a natureza da ciência que professores e estudantes de Física detêm, e sua influência no ensino e aprendizagem da Física. Este trabalho procura responder a uma versão dessa investigação: quais as relações, caso existam, entre as concepções epistemológicas de professores de Física e suas práticas didáticas? A pesquisa nessa linha tem noticiado esforços visando melhorar o ensino de ciências em vários países do mundo, há várias décadas. No Brasil, os Parâmetros Curriculares Nacionais (PCN) e as Orientações Curriculares para o Ensino Médio destacam a importância do desenvolvimento de um ensino de ciências voltado à formação da “[...] autonomia crítica do educando, esta deve dar-se sob três aspectos: intelectual, político e econômico [...]; da alfabetização científica e tecnológica [...] para que os alunos compreendam a predominância de aspectos técnicos e científicos na tomada de decisões sociais significativas [...]" (BRASIL, 2006, p. 46-47).

Nesse sentido, os documentos oficiais recomandam que, por meio da Filosofia da Ciência, o professor construa uma concepção de ciência que lhe permita abordá-la em sala de aula de forma a incentivar a emergência de uma visão científica e crítica nos alunos. Nos EUA, a American Association for the Advancement of Science (AAAS) recomendou, em 1989, um ensino de ciências mais contextualizado histórica e filosoficamente (MATTHEWS, 1995); o movimento atual chamado Physics First, sob o slogan da American Association of Physics Teachers (AAPT) de Physics for All (PHYSICS..., 2006), tem sérias preocupações com a alfabetização científica. Na Europa, o trabalho de um grupo de físicos, que obteve reconhecimento da European Physical Society, tem sido no sentido de rejeitar o ensino tradicional de Física, baseado em livros de texto, e incentivar uma nova abordagem baseada na História e na Filosofia da Física contemporâneas, com novas estratégias e argumentações, buscando diminuir o gap entre a pesquisa científica e o ensino da Física (BEVILACQUA; GIANNETTO, 1996).

Essas iniciativas, ainda que orientadas por distintas perspectivas, têm em comum uma preocupação com a melhoria das visões sobre a natureza da ciência. Duas crenças sustentam tais projetos: a de que as pessoas têm uma ideia equivocada sobre a ciência, inclusive os próprios cientistas (MATTHEWS, 2010, tradução nossa); e a de que um entendimento mais adequado da natureza da ciência pode contribuir para a melhoria do ensino de ciências (LEDERMAN, 1992; McDONALD, 2010; MEICHTRY, 1993).

Possivelmente, uma das mais severas causas da inércia na inserção de aspectos da natureza da ciência no Ensino Médio possa estar na lenta mudança dos pontos de vista dos professores de Ciências e de Física, em particular. Esse processo de mudança epistemológica parece exigir alterações na formação inicial e continuada, focando-se na necessidade de construir novas posturas dos professores com o fim de conscientizá-los de seu importante papel na promoção da reflexão crítica e participativa de seus alunos, preparando-os para um mundo em permanente transformação (RICARDO; CUSTÓDIO; REZENDE JR., 2008). Nesse sentido, o presente trabalho visa investigar possíveis relações entre o entendimento da natureza da ciência de professores de Física do Ensino Médio e as estratégias didáticas por eles privilegiadas. Pretende-se, ainda, vislumbrar possíveis influências de concepções mais alinhadas às visões epistemológicas contemporâneas (VEC), para a melhoria do ensino de Física. Assume-se, aqui, o pressuposto, justificado na literatura (EL-HANI; TAVARES; ROCHA, 2004; LEDERMANN, 1992; MAT- 
THEWS, 2009; MESTRE, 2001; RYDER; LEACH; DRIVER, 1999), de que o ensino de Física é mais eficaz quando realizado sob uma abordagem contextualizada histórica e filosoficamente.

\section{Revisão da literatura}

A Filosofia e a História da Ciência têm tomado parte ativamente no debate para reformular o ensino de ciências, discutindo visões e concepções, propondo estratégias e abordagens, mas com um sucesso limitado. $\mathrm{O}$ uso de metodologias instrucionais explícitas para discutir a natureza da ciência vem sendo defendido na literatura sob o argumento de que: (i) elas favorecem a reflexão de professores e estudantes (BELL; LEDERMAN; ABD-EL-KHALICK, 1998; MORRISON; RAAB; INGRAM, 2009); (ii) permitem argumentar e envolver os estudantes na compreensão da origem e contextualização teórico-histórica das leis e teorias, incluindo o surgimento e a superação de controvérsias (MOREIRA, 2007; RENN, 2004; SILVA; MOURA, 2008; SOLOMON; DUVEEN; SCOT, 1992); (iii) possibilitam desmistificar a construção do conhecimento científico como um processo de buscas cegas (MELO; PEDUZZI, 2007), e (iv) auxiliam a perceber os conceitos físicos como "menos mágicos" e participantes do cotidiano (BRAKE; HOOK, 2007; ESPINOZA, 2005). Esses argumentos auxiliam a refletir sobre a relevância de intervenções pedagógicas contextualizadas, do ponto de vista epistemológico.

No entanto, uma revisão da literatura para uma tese de doutorado (MASSONI, 2010) mostrou que ainda é pequena a quantidade de trabalhos que investigam as relações entre as visões epistemológicas dos professores e suas práticas docentes. Lederman (1999) relatou estudos de caso com professores de Biologia e verificou que a internalização de visões epistemológicas adequadas ${ }^{2}$ mostrou ser um importante objetivo instrucional no planejamento de muitas unidades de ensino. Sandoval, Cudmani e Madozzo (1995, tradução nossa) atribuem à incorreta compreensão, por parte dos docentes, da natureza do trabalho científico, e a inadequadas estratégias educativas derivadas dessas visões, o fracasso de algumas propostas inovadoras de ensino de ciências. Por sua vez, Hashweh (1996) relatou uma pesquisa que mapeou as concepções de um grupo de professores de ciências palestinos e as ações instrucionais que eles informaram utilizar, e obteve que professores que tinham concepções mais contemporâneas mostravam-se melhor preparados para combinar diferentes estratégias didáticas. De modo semelhante, Sawyer (2002) obteve que professores de ciências combinavam vários elementos nas suas práticas, tais como: autonomia, colaboração da prática, improvisação e experimentação. Martins (2007), por meio de um diagnóstico com grupos de professores e futuros professores, em Rondônia, obteve que eles se interessam mais por História da Ciências, e que, embora atribuam importância à Filosofia da Ciência, dificilmente a incorporam em suas aulas. Peme-Aranega et al. (2009), em um estudo de caso com uma professora de Física do Ensino Secundário, observaram que seu modelo didático se mostrou tradicional nos primeiros anos, ainda que suas concepções didáticas

\footnotetext{
${ }^{2}$ Por adequadas, entendem-se, aqui, visões alinhadas a posturas mais contemporâneas, chamadas, neste texto, de "visões epistemológicas contemporâneas" ou "VEC", e que constituem uma nova maneira de conceber a natureza da ciência, seu "método" e sua evolução histórica.
} 
e epistemológicas fossem atuais, e que houve uma evolução gradual nos seus comportamentos verbais com o amadurecimento profissional. Esses resultados parecem mostrar, por distintas razões, certo consenso, entre os pesquisadores, sobre a relevância da inserção de elementos da História e Filosofia da Ciência na formação de professores e no ensino de ciências.

Blanton (2003) argumentou que, se, de um lado, o currículo é definido previamente, de outro, a escolha do método pelo qual o estudante adquire domínio dos conceitos e desenvolve modelos do mundo físico depende da sensibilidade artística do professor para: propor atividades diferenciadas, motivar trabalhos de grupo, encorajar a argumentação e a exposição de ideias de seus estudantes. Nessa linha, Harres (1999), em revisão da literatura que abrangeu várias décadas, ratificou que o professor é uma variável relevante no processo educativo, e que este não consegue promover um entendimento adequado se ele próprio detém inadequadas concepções da natureza da ciência (CNC). Os resultados indicavam: o empirismo como imagem da ciência dominante, especialmente entre professores mais experientes; e certa incoerência das pesquisas sobre as $\mathrm{CNC}$ evolutivo-construtivistas, e, ainda, uma concepção pedagógica de que o conhecimento escolar é um produto acabado e formal. Advertiu que a simples aquisição de visões contextualizadas não garante aos professores uma performance adequada para mudar as visões de seus estudantes, e que é fundamental, no processo formativo dos professores, que ocorram reflexões críticas sobre a natureza da ciência. Harres (1999) indicou, ainda, que um conhecimento sobre o conhecimento organiza o pensamento do professor e tem implicações na prática docente.

De modo geral, defende-se que é importante que os professores de ciências adquiram o hábito de refletir suas concepções e de avaliar suas estratégias didáticas, solicitando conselhos e opiniões de outros professores, dado que as técnicas, assim como a ciência, passam por uma contínua remodelação ao longo do tempo. Espera-se que a escola coloque, nos estudantes, os fundamentos sobre os quais o conhecimento possa ser (re)construído, que os professores estejam conscientes do seu papel fundamental no tipo de estrutura cognitiva que o estudante pode desenvolver, e que os currículos contemporâneos de ciências adotem uma perspectiva de aprendizagem dos conteúdos da ciência e de algo mais, algo sobre as ciências (MATTHEWS, 2009) em um esforço voltado também a aspectos não científicos e suas interações com a cultura e a sociedade. Mas, reconhece esse autor, que existem muitas dificuldades a serem superadas para que isso se torne uma realidade de sala de aula.

Algumas dessas dificuldades, perspectivas de superação, bem como outras questões de contexto, é o que se busca discutir no presente trabalho.

\section{O contexto da investigação}

O presente trabalho é parte de um estudo mais abrangente que buscou investigar as contribuições da Epistemologia Contemporânea e questões da mudança epistemológica nas práticas docentes em Física (MASSONI, 2010). Nessa investigação, foram realizados cinco estudos de caso etnográficos, que passamos a resumir:

- Estudo I envolveu uma turma de futuros professores de Física, em que se buscou mapear suas concepções epistemológicas e a evolução dessas concepções ao longo de uma 
disciplina específica, História e Epistemologia da Física, obrigatória no curso de Licenciatura em Física, na UFRGS (MOREIRA; MASSONI; OSTERMANN, 2007);

- Estudo II envolveu 27 professores, a maioria já atuantes, que cursavam uma disciplina de Epistemologia e Ensino de Física, no curso de Mestrado Profissional em Ensino de Física da UFRGS, em 2007, em formato de curso de verão (MASÓN; MOREIRA, 2007);

- Estudo III, realizado com um professor de Física que tem concepções epistemológicas sabidamente alinhadas às visões epistemológicas contemporâneas, ou VECs, tendo participado como aluno de graduação e de pós-graduação, dos Estudos I e II, e atuando em uma escola particular de Porto Alegre, RS (MASSONI; MOREIRA, 2010);

- Estudo IV, realizado com um professor de Física atuando em uma escola militar de Porto Alegre e cujas concepções epistemológicas não eram inicialmente conhecidas, mas que foi possível identificá-las por meio de análise interpretativa de entrevista semiestruturada com o professor, de diálogos e dados de campo oriundos da imersão em sala de aula, e que se mostraram não alinhadas às VECs e mais adequadas a concepções empírico-indutivistas sobre a ciência (MASSONI; MOREIRA, 2011);

- Estudo V, realizado com uma professora de Física atuando em uma escola da rede pública estadual e que tem concepções pelo menos parcialmente alinhadas às VECs, tendo cursado uma disciplina de Epistemologia similar à descrita no Estudo II (MASSONI; MOREIRA, 2012).

\section{Objetivo e metodologia}

Pretende-se, neste relato, cruzar três estudos de caso etnográficos: Estudos III, IV e V, que compõem a mencionada pesquisa mais ampla, que abrangeu cinco estudos. Busca-se, então, sistematizar e comparar dados de pesquisa qualitativa na tentativa de chegar a alguns achados comuns ou a uma "teoria fundamentada" (STRAUSS; CORBIN, 2008, p. 25).

A pesquisa na qual se inserem os três estudos aqui abordados buscou responder, tanto quanto possível, por intermédio de pesquisa qualitativa, descritiva, interpretativa, cinco questões de pesquisa. Dessas, citamos aqui três que estão relacionados aos objetivos deste trabalho

1) Concepções epistemológicas alinhadas às chamadas "visões epistemológicas contemporâneas" contribuem de forma efetiva na transformação e melhoria das práticas didáticas dos professores de Física que atuam no Ensino Médio, no sentido de torná-los mais críticos e reflexivos?;

2) Como acontece a transposição didática dos conhecimentos sobre epistemologia adquiridos, refletidos e discutidos ao longo da formação, pelos professores de Física que tiveram esse tipo de iniciação?;

3) Há diferenças perceptíveis nas práticas docentes com relação àqueles professores que não tiveram este tipo de formação? Como já dito, o presente trabalho cinge-se ao cruzamento dos três últimos estudos de caso indicados no item 2, ou seja, os das escolas particular, militar e pública.

Em Massoni e Moreira (2010, 2011, 2012), são apresentadas descrições compreensivas da dinâmica de sala de aula, nas aulas de Física, de três distintas culturas escolares, por meio de imersão no ambiente natural dos eventos (Estudos III, IV e V), em que se buscou interpretar 
as ações e movimentos sob a perspectiva dos atores envolvidos, de forma densa e rica em contexto. O cruzamento desses estudos, que aqui se apresenta, busca vislumbrar relações (e se há) entre as visões epistemológicas de três professores de Física e suas práticas didáticas, e, também, compreender se elementos da natureza da ciência se fazem presentes em suas aulas e se auxiliam na melhoria do ensino de Física. Espera-se, também, que este cruzamento possa servir como motivação para a autorreflexão de professores de Física, na medida em que pontos fortes e/ou debilidades de distintas realidades escolares são enfocadas.

\section{Uma análise cruzada de três estudos de caso etnográficos com professores de Física}

Após longo período de imersão em sala de aula, que se estendeu por um semestre em cada escola, e depois de uma análise descritiva e interpretativa de cada estudo etnográfico (MASSONI, 2010), foi possível identificar, nas distintas culturas escolares, alguns aspectos considerados mais relevantes no que tange: às condições materiais, ao planejamento dos conteúdos, à organização, à estrutura, aos objetivos gerais das diferentes escolas e, especialmente, às estratégias didáticas dos professores de Física envolvidos.

Uma visualização de aspectos relevantes dos distintos contextos escolares é mostrada no Quadro 1, com o intuito de oferecer um panorama geral e facilitar uma análise cruzada dos estudos, tendo presente que trabalhamos com casos e não temos a pretensão de generalizar.

O exame do Quadro 1 sugere que, dos três estudos de caso etnográficos realizados com professores de Física atuando em diferentes tipos de escolas de Porto Alegre, foi na escola militar onde se observou o melhor rendimento dos alunos, avaliados nos padrões tradicionais, por meio de testes e provas escritas. Esta foi, também, a escola onde as chamadas "visões epistemológicas contemporâneas" menos estiveram presentes nas aulas de Física, pois o Prof. B demonstrou, ao longo da observação participante e da análise interpretativa de entrevista semiestruturada, deter concepções empírico-indutivistas sobre a natureza da ciência.

Contudo, há que se considerar certos aspectos peculiares da escola militar onde os alunos, em geral, têm bom nível de conhecimentos gerais, são oriundos de famílias capazes de custear e incentivar uma intensiva preparação para o ingresso à escola, que se dá por concurso público. Além disso, a escola focaliza a organização, a disciplina, o rigor em aspectos como horários, construção de hábito pelo estudo diário, oferecendo condições e professores para estudo extraclasse. Isso se converte em um diferencial frente às outras escolas, e daí decorre certa dificuldade em se comparar os achados.

Ainda assim, das narrativas etnográficas densas e de aspectos resumidos no Quadro 1, percebe-se que o Prof. A e o Prof. C (Estudos III e V) demonstraram ter certa preocupação com aspectos relacionados com a natureza da ciência, buscando destacar a natureza construtiva das leis e teorias da Física, bem como o importante papel que assumem modelos científicos na construção do conhecimento. Esses docentes iniciaram algumas discussões que poderiam ter resultado em reflexões críticas pelos alunos, mas se observou que não souberam operacionalizar adequadamente as oportunidades por eles próprios criadas, deixando as discussões inconclusas ou não explicitando, abertamente, suas intenções do ponto de vista epistemológico. Dessa forma, converteram-se em tentativas tímidas e desarticuladas de inserir visões contemporâneas da natureza da ciência em suas estratégias didáticas. 
Quadro 1. Comparativo dos principais aspectos observados nos estudos de caso III, IV e V, realizados em três escolas de Ensino Médio de Porto Alegre, RS, em 2007 e 2008

\begin{tabular}{|c|c|c|c|}
\hline Estudo & Estudo de caso III & Estudo de caso IV & Estudo de caso V \\
\hline Tipo de escola & Particular & Militar & Pública \\
\hline Turma observada & $2^{\circ}$ ano do Ensino Médio & $2^{\circ}$ ano do Ensino Médio & $3^{\circ}$ ano do Ensino Médio \\
\hline $\begin{array}{l}\text { Período de } \\
\text { observação }\end{array}$ & $\begin{array}{l}2007 / 2 \\
41 \text { horas-aula }\end{array}$ & $\begin{array}{l}2008 / 1 \\
37 \text { horas-aula }\end{array}$ & $\begin{array}{l}2008 / 2 \\
49 \text { horas-aula }\end{array}$ \\
\hline $\begin{array}{l}\mathrm{N}^{\circ} \text { de alunos } \\
\text { nas turmas } \\
\text { observadas }\end{array}$ & 41 & 28 & $\begin{array}{l}37 \\
\text { (18 concluíram o ano letivo) }\end{array}$ \\
\hline $\begin{array}{l}\text { Tamanho da sala } \\
\text { versus número de } \\
\text { alunos }\end{array}$ & Pequena & Grande & Adequada \\
\hline $\begin{array}{l}\text { Condições e } \\
\text { instalações da } \\
\text { escola }\end{array}$ & $\begin{array}{l}\text { Boas (prédio bem } \\
\text { conservado, classes e } \\
\text { cadeiras em bom estado, } \\
\text { ar condicionado, cortinas } \\
\text { na sala de aula, ginásio } \\
\text { de esportes adequado, } \\
\text { laboratórios precários } \\
\text { e grande número de } \\
\text { alunos em salas de aula } \\
\text { pequenas). }\end{array}$ & $\begin{array}{l}\text { Muito boas (prédios } \\
\text { amplos, quadras abertas } \\
\text { para esportes, salões } \\
\text { para cerimoniais, tudo em } \\
\text { excelentes condições, } \\
\text { classes e cadeiras limpas } \\
\text { e em bom estado, sala de } \\
\text { aula impecavelmente limpa, } \\
\text { organizada e espaçosa, } \\
\text { laboratórios e bibliotecas } \\
\text { amplos e bem equipados). }\end{array}$ & $\begin{array}{l}\text { Ruins (prédios amplos e } \\
\text { mal conservados dando } \\
\text { a impressão de certo } \\
\text { abandono, classes e } \\
\text { cadeiras em péssimas } \\
\text { condições, sala suja, } \\
\text { desorganizada, lixo } \\
\text { espalhado pela sala, } \\
\text { biblioteca e laboratórios } \\
\text { moderadamente equipados, } \\
\text { mas subutilizados). }\end{array}$ \\
\hline $\begin{array}{l}\text { Adoção de livro } \\
\text { de texto (livro } \\
\text { didático) ou } \\
\text { apostila? }\end{array}$ & Sim. Adotavam apostila. & $\begin{array}{l}\text { Sim. Adotavam livro de } \\
\text { texto. }\end{array}$ & $\begin{array}{l}\text { Não utilizavam livro de } \\
\text { texto, nem apostilas. }\end{array}$ \\
\hline $\begin{array}{l}\text { Objetivos gerais } \\
\text { percebidos }\end{array}$ & $\begin{array}{l}\text { A escola como uma } \\
\text { empresa: funcionar bem, } \\
\text { ser competitiva, manter } \\
\text { e aumentar o número de } \\
\text { alunos. }\end{array}$ & $\begin{array}{l}\text { Ensino de bom nível e } \\
\text { constante preocupação } \\
\text { em manter uma tradição } \\
\text { histórica de eficiência, } \\
\text { disciplina, valores morais e } \\
\text { respeito. }\end{array}$ & $\begin{array}{l}\text { Cumprimento de políticas } \\
\text { públicas relativas à oferta } \\
\text { de ensino gratuito. Mas } \\
\text { não se percebiam objetivos } \\
\text { comuns entre direção, } \\
\text { corpo docente e corpo } \\
\text { discente. }\end{array}$ \\
\hline $\begin{array}{l}\text { Docente } \\
\text { observado }\end{array}$ & Prof. A & Prof. B & Prof. C \\
\hline $\begin{array}{l}\text { Comportamento } \\
\text { geral dos alunos } \\
\text { em aula } \\
\text { epistemológicas } \\
\text { contemporâneas? }\end{array}$ & $\begin{array}{l}\text { Conversas frequentes e um } \\
\text { ruído de fundo permanente } \\
\text { marcavam as aulas, mas os } \\
\text { alunos atendiam aos apelos } \\
\text { do professor e deixavam } \\
\text { transparecer um clima de } \\
\text { cordialidade em sala de } \\
\text { aula. }\end{array}$ & $\begin{array}{l}\text { Disciplina, silêncio, respeito, } \\
\text { concentração com os } \\
\text { estudos, preocupação em } \\
\text { obter bom desempenho nas } \\
\text { avaliações quase semanais, } \\
\text { e certo ar de formalidade } \\
\text { marcavam todas as aulas. }\end{array}$ & $\begin{array}{l}\text { Conversas intensas, } \\
\text { desconcentração, ruídos } \\
\text { com objetos, classes e } \\
\text { cadeiras eram constantes; } \\
\text { demonstravam carinho com } \\
\text { o Prof. C, mas, ao mesmo } \\
\text { tempo, assumiam com } \\
\text { facilidade certas atitudes } \\
\text { hostis. }\end{array}$ \\
\hline
\end{tabular}


Quadro 1. continuação

\begin{tabular}{|c|c|c|c|}
\hline Estudo & Estudo de caso III & Estudo de caso IV & Estudo de caso V \\
\hline $\begin{array}{l}\text { Relações } \\
\text { docente-discentes }\end{array}$ & $\begin{array}{l}\text { Amistosas. Brincadeiras e } \\
\text { diálogos francos deixavam } \\
\text { transparecer relações de } \\
\text { amizade entre alunos e } \\
\text { docente. }\end{array}$ & $\begin{array}{l}\text { Respeitosas. As } \\
\text { brincadeiras partiam, } \\
\text { invariavelmente, do docente } \\
\text { e tinham, ao que parecia, o } \\
\text { objetivo de descontrair. }\end{array}$ & $\begin{array}{l}\text { Camaradagem. Atitudes } \\
\text { condescendentes deixavam } \\
\text { transparecer afetuosidade } \\
\text { do docente para com os } \\
\text { alunos, mas o inverso nem } \\
\text { sempre era percebido. } \\
\text { Havia grande dose de } \\
\text { indisciplina, irreverência } \\
\text { e descaso para com a } \\
\text { aprendizagem. }\end{array}$ \\
\hline $\begin{array}{l}\text { Visões } \\
\text { epistemológicas } \\
\text { demonstradas } \\
\text { pelo docente }\end{array}$ & $\begin{array}{l}\text { Alinhadas às visões } \\
\text { epistemológicas } \\
\text { contemporâneas (VEC ou } \\
\text { visões surgidas ao longo do } \\
\text { séc. XX). }\end{array}$ & $\begin{array}{l}\text { Visões epistemológicas } \\
\text { tipicamente empírico- } \\
\text { indutivistas (superadas } \\
\text { pela epistemologia } \\
\text { contemporânea). }\end{array}$ & $\begin{array}{l}\text { Parcialmente alinhadas } \\
\text { às visões epistemológicas } \\
\text { contemporâneas (VECs) } \\
\text { em vários aspectos, mas } \\
\text { não em todos. }\end{array}$ \\
\hline $\begin{array}{l}\text { Estratégias } \\
\text { didáticas }\end{array}$ & $\begin{array}{l}\text { Prof. A procurava } \\
\text { diversificar suas estratégias } \\
\text { didáticas, incluindo aulas } \\
\text { expositivas, discussões de } \\
\text { grande grupo, trabalhos } \\
\text { em pequenos grupos, } \\
\text { resoluções de exercícios, } \\
\text { pequenas demonstrações, } \\
\text { debates abertos; sugerindo } \\
\text { trabalhos de pesquisa, } \\
\text { apresentação e discussão } \\
\text { dos resultados desses } \\
\text { trabalhos. }\end{array}$ & $\begin{array}{l}\text { Prof. B centrava suas } \\
\text { estratégias em aulas } \\
\text { expositivas (objetivas) e } \\
\text { na resolução dirigida de } \\
\text { exercícios. Fazia uso de } \\
\text { raciocínios lógicos, gráficos } \\
\text { e de rigoroso formalismo } \\
\text { matemático. }\end{array}$ & $\begin{array}{l}\text { Prof. C fazia uso de aulas } \\
\text { expositivas, esquemas } \\
\text { e resumos escritos no } \\
\text { quadro; resolução de } \\
\text { exercícios em aula e } \\
\text { indicando extensas listas de } \\
\text { exercícios; oferecia auxílio } \\
\text { na resolução, atendendo os } \\
\text { alunos nas suas classes, } \\
\text { de forma individualizada e } \\
\text { segmentada, parecendo } \\
\text { pouco proveitosa; fazia } \\
\text { demonstrações que } \\
\text { os alunos apreciavam, } \\
\text { mas desperdiçava boas } \\
\text { oportunidades de revisitar } \\
\text { conceitos e teorias, pois } \\
\text { não promovia discussões } \\
\text { de grande grupo. }\end{array}$ \\
\hline $\begin{array}{l}\text { Rendimento } \\
\text { em avaliações } \\
\text { escritas (provas/ } \\
\text { testes) }\end{array}$ & Regular & Bom & Ruim \\
\hline $\begin{array}{l}\text { Organização, } \\
\text { planejamento } \\
\text { e gestão de } \\
\text { conteúdos de } \\
\text { ensino }\end{array}$ & $\begin{array}{l}\text { Regular. Foi notável certa } \\
\text { falta de planejamento das } \\
\text { aulas, comprometendo a } \\
\text { abrangência dos conteúdos; } \\
\text { debates longos e com perda } \\
\text { de foco; má distribuição do } \\
\text { tempo. }\end{array}$ & $\begin{array}{l}\text { Bom do ponto de } \\
\text { vista tradicional. Aulas } \\
\text { planejadas, precisas } \\
\text { (explicações claras e } \\
\text { objetivas) e rigoroso } \\
\text { cumprimento dos conteúdos } \\
\text { programados e bastante } \\
\text { abrangentes. }\end{array}$ & $\begin{array}{l}\text { Ensino descontínuo, } \\
\text { excessiva perda de aulas, } \\
\text { resultando em rendimento } \\
\text { abaixo do desejável. } \\
\text { Conteúdos minimamente } \\
\text { abordados; aparente } \\
\text { ausência de controle em } \\
\text { sala de aula, perda de foco } \\
\text { com relação aos objetivos } \\
\text { propostos no planejamento } \\
\text { prévio (que ficou apenas no } \\
\text { papel); má distribuição do } \\
\text { tempo. }\end{array}$ \\
\hline
\end{tabular}


Quadro 1. continuação

\begin{tabular}{|l|l|l|l|}
\hline \multicolumn{1}{|c|}{ Estudo } & \multicolumn{1}{|c|}{ Estudo de caso III } & \multicolumn{1}{c|}{ Estudo de caso IV } & \multicolumn{1}{c|}{ Estudo de caso V } \\
\hline $\begin{array}{l}\text { Docente fez } \\
\text { uso das visões } \\
\text { epistemológicas } \\
\text { contemporâneas? }\end{array}$ & $\begin{array}{l}\text { Prof. A manteve presente } \\
\text { essa preocupação, mas } \\
\text { privilegiou abordagens } \\
\text { implícitas e muitas vezes } \\
\text { desarticuladas. Criou } \\
\text { inúmeras situações } \\
\text { favoráveis à exploração das } \\
\text { suas próprias convições } \\
\text { epistemológicas, mas } \\
\text { acabou desperdiçando } \\
\text { boas oportunidades por } \\
\text { não conduzir os debates } \\
\text { e demonstrar certo } \\
\text { despreparo na gestão } \\
\text { dessa ferramenta. }\end{array}$ & $\begin{array}{l}\text { alusão implícita às próprias } \\
\text { convicções marcadamente } \\
\text { empírico-indutivistas. }\end{array}$ & $\begin{array}{l}\text { Prof. C demonstrou } \\
\text { frequente preocupação } \\
\text { com essas questões; } \\
\text { falou repetidas vezes } \\
\text { em modelos científicos } \\
\text { embora não tenha tido o o } \\
\text { cuidado de alertar, de forma } \\
\text { explícita, para seu papel na } \\
\text { construção da ciência, e de } \\
\text { ensejar esforços para que } \\
\text { não fossem confundidos } \\
\text { com a realidade; iniciou, } \\
\text { em uma das aulas, um } \\
\text { debate sobre a natureza } \\
\text { da ciência, mas que se } \\
\text { mostrou pouco proveitoso } \\
\text { para os alunos, pois ficou } \\
\text { inconcluso e nunca chegou } \\
\text { a ser retomado. }\end{array}$ \\
& & & \\
& &
\end{tabular}

Fonte: Elaborado pelos autores.

Destaca-se, contudo, que não houve essa mesma intencionalidade na escola militar. Para Astolfi e Develay (2008, p. 12-13), toda proposta didática integra três reflexões:

[...] uma epistemológica (aquela que pode dar conta da lógica dos saberes...); uma reflexão psicológica (aquela que pode dar conta da lógica da apropriação dos saberes em geral); e uma reflexão pedagógica (aquela que se ancora mais ainda nas ciências da relação, relações com os alunos, situações de classe, discurso do docente, condições de aprendizagem dos saberes, questões da vitória e do fracasso escolar, etc.).

Segundo esses autores, a reflexão epistemológica propõe-se a examinar a estrutura do saber ensinado: quais são os principais conceitos que funcionam na disciplina, quais relações unem esses conceitos, qual é o status da noção de lei, de teoria, quais retificações sucessivas de sentido se produzem na história desses conceitos. Bachelard (1988), cujas ideias ainda se mostram atuais, colocou, em termos de rupturas e obstáculos, a abordagem histórica dos conceitos científicos, enfatizando a não-linearidade do progresso do pensamento científico. Sugeriu que, dentro do próprio ato de conhecer, surgem causas de estagnação e inércia, ou obstáculos epistemológicos, e que sua superação resulta em avanços ao espírito científico e é um convite para pensar a ciência em termos de rupturas mais do que de continuidade.

Por isso, se destaca a importância da inserção, nas aulas de Física, de discussões epistemológicas, para tornar o ensino científico mais reflexivo, para que permita, aos alunos, responderem a questões científicas e técnicas da vida cotidiana, além de desenvolverem atitudes e formas de pensamento próximas daquelas de que a ciência lança mão. 
Pensamos que o professor de Física é o eixo propulsor desse processo. Nesse sentido, buscamos aclarar possíveis relações entre as concepções epistemológicas dos professores observados e as estratégias didáticas por eles privilegiadas. Destaque-se que os relatos dos estudos de caso limitam-se ao seu contexto, e não constituem, de forma alguma, tentativas de generalização. Contudo, guiados pelo referencial metodológico da teoria fundamentada de Strauss e Corbin (2008), tentou-se organizar os dados de forma a se construírem categorias que permitissem comparar os estudos de caso e chegar a alguma explicação, ou seja, a certas afirmações consistentemente inter-relacionadas, capazes de explicar o observado ao longo da investigação. Para Bogdan e Biklen (1994, p. 205), a análise de dados qualitativos envolve "organização, divisão em unidades manipuláveis, síntese, procura de padrões, descoberta de aspectos importantes do que deve ser aprendido e a decisão sobre o que vai ser transmitido aos outros [...]”, com o fim de se chegar, interpretativamente, a achados de pesquisa. Procuramos fazer isto localizando os fenômenos (as práticas e os movimentos dos docentes de Física em sala de aula) nos diferentes contextos, de forma sucinta, comparando e visualizando pontos comuns ou divergentes.

Assim, o Quadro 2 busca descrever, por meio de palavras-chave, as ações centrais, padronizadas tanto quanto possível, que marcaram as aulas dos docentes observados (Profs. A, B e C). Esclarece-se que, no Estudo IV (Prof. B), o número de observações participantes totalizou 37 horas-aula, enquanto, nos outros dois estudos, o número foi superior. O objetivo da pesquisa em educação, qualquer que seja a metodologia, é responder a perguntas estimulantes mantendo certo grau de rigor, baseando a análise em dados e fazendo uso da criatividade para organizar, categorizar, comparar e extrair esquemas inovadores capazes de oferecer uma explicação dos fenômenos de interesse. Segundo Strauss e Corbin (2008, p. 91-93), é importante, nesse tipo de pesquisa, manter o equilíbrio entre ciência e criatividade, entre objetividade e sensibilidade, pois o pesquisador é, nos estudos qualitativos, um instrumento de análise. Uma ferramenta útil para auxiliar a reconhecer tendências e a fazer comparações é responder a uma sequência de perguntas específicas como: Fez o quê? Como? Onde? Por quê? É o que se busca fazer por meio da construção do Quadro 2.

Para auxiliar na análise do Quadro 2, foram construídas quatro categorias buscando agrupar as diferentes estratégias adotadas pelos professores: Estratégia inovadora, quando se destacou das demais utilizadas pelo docente, por ser diferente ou nova; Estratégia diversificada, quando o professor fez uso de diferentes táticas em uma mesma aula. Por exemplo: aula teórica ou resolução de exercícios com discussões abertas, ou acompanhadas de pequenas demonstrações etc.; Estratégia tradicional, quando foi a tipicamente tradicional, baseada em aula expositiva e/ou resolução de exercícios conduzida pelo professor, ou aplicação de avaliações escritas; e uma quarta categoria foi chamada de Aula suspensa, para englobar horas-aula envolvendo outras atividades da escola que não aulas de Física, paralisações, suspensão de aula por falta de professor etc..

O resultado do agrupamento das aulas nas distintas categorias é mostrado na Tabela 1.

A inspeção da Tabela 1 indica que o Prof. B (Estudo IV) utilizou, preferencialmente, estratégias tradicionais, com aulas expositivas e de resolução de exercícios, e foi quem menos incluiu estratégias diversificadas e inovadoras em suas aulas. 
Quadro 2. Palavras-chave que marcaram as atividades/ações centrais desenvolvidas pelos professores de Física dos Estudos III, IV e V, ao longo de 37 horas-aula observadas em três distintas escolas de Porto Alegre

\begin{tabular}{|c|c|c|c|}
\hline \multicolumn{4}{|c|}{$\begin{array}{l}\text { Principais ações/atividades dos professores de Física } \\
\text { observados nos estudos de caso III, IV e V (descritos no item 2) }\end{array}$} \\
\hline & Estudo III (escola particular) & Estudo IV (escola militar) & Estudo V (escola pública) \\
\hline A1 & $\begin{array}{l}\text { Resolução de exercícios e } \\
\text { esclarecimento de dúvidas de } \\
\text { Termodinâmica; preparação } \\
\text { para prova. }\end{array}$ & $\begin{array}{l}\text { Resolução detalhada de } \\
\text { exercícios de Termodinâmica } \\
\text { (uso do livro de texto). }\end{array}$ & $\begin{array}{l}\text { Monitoramento da tarefa de } \\
\text { resolução de exercícios de } \\
\text { Eletrodinâmica, atendimento } \\
\text { individual; preparação para } \\
\text { prova. }\end{array}$ \\
\hline $\mathrm{A} 2$ & $\begin{array}{l}\text { Revisão teórica com } \\
\text { demonstrações simples; } \\
\text { preparação para prova. }\end{array}$ & $\begin{array}{l}\text { Resolução de exercícios e } \\
\text { esclarecimento de dúvidas; } \\
\text { preparação para a avaliação } \\
\text { parcial (AP). }\end{array}$ & $\begin{array}{l}\text { Monitoramento da tarefa } \\
\text { de resolução de exercícios; } \\
\text { sugerida discussão em } \\
\text { pequenos grupos. }\end{array}$ \\
\hline A3 & $\begin{array}{l}\text { Revisão teórica e debate de } \\
\text { ideias com os alunos. }\end{array}$ & $\begin{array}{l}\text { Resolução de exercícios e } \\
\text { aplicação da Avaliação Parcial } \\
\text { (AP). }\end{array}$ & $\begin{array}{l}\text { Monitoramento da tarefa } \\
\text { de resolução de exercícios; } \\
\text { atendimento individual e em } \\
\text { duplas. }\end{array}$ \\
\hline A4 & Aplicação da prova bimestral. & $\begin{array}{l}\text { Resolução detalhada de } \\
\text { exercícios, esclarecimento de } \\
\text { dúvidas; preparação para prova. }\end{array}$ & $\begin{array}{l}\text { Apresentação de resumo; } \\
\text { esclarecimento de dúvidas. }\end{array}$ \\
\hline A5 & $\begin{array}{l}\text { Correção da prova, identificação } \\
\text { e discussão refletida de erros } \\
\text { mais comuns; preparação da } \\
\text { prova de recuperação. }\end{array}$ & Aplicação da prova bimestral. & $\begin{array}{l}\text { Teórica: introdução à corrente } \\
\text { elétrica, com levantamento de } \\
\text { ideias prévias (sobre corrente) e } \\
\text { negociação de significados. }\end{array}$ \\
\hline A6 & $\begin{array}{l}\text { Revisão teórica do conteúdo do } \\
\text { bimestre. }\end{array}$ & Aplicação da prova bimestral. & $\begin{array}{l}\text { Aula deveria ocorrer no } 4^{\circ} \\
\text { período; antecipação para o } \\
3^{\circ} \text { por falta de professor nesse } \\
\text { período; envio de exercícios aos } \\
\text { alunos pelo docente de Física, } \\
\text { que atendia outra turma. }\end{array}$ \\
\hline A7 & $\begin{array}{l}\text { Revisão teórica do conteúdo } \\
\text { (continuação). }\end{array}$ & $\begin{array}{l}\text { Teórica: introdução ao } \\
\text { comportamento dos gases. }\end{array}$ & $\begin{array}{l}\text { Teórica: circuitos elétricos, com } \\
\text { demonstração de um circuito } \\
\text { simples e colocação livre de } \\
\text { ideias, pelos alunos, sobre seu } \\
\text { funcionamento. }\end{array}$ \\
\hline A8 & $\begin{array}{l}\text { Aplicação da prova de } \\
\text { recuperação. }\end{array}$ & $\begin{array}{l}\text { Aula cedida a outra disciplina: } \\
\text { semana de provas da escola. }\end{array}$ & $\begin{array}{l}\text { Discussão das ideias sobre } \\
\text { demonstração do circuito; } \\
\text { exercícios e exemplos; } \\
\text { preparação para prova. }\end{array}$ \\
\hline A9 & $\begin{array}{l}\text { Teórica: introdução a máquinas } \\
\text { térmicas. }\end{array}$ & $\begin{array}{l}\text { Aula cedida a outra disciplina: } \\
\text { semana de provas da escola. }\end{array}$ & $\begin{array}{l}\text { Revisão teórica e refletida; } \\
\text { exercícios como revisão para } \\
\text { prova (continuação). }\end{array}$ \\
\hline A10 & $\begin{array}{l}\text { Seminário no anfiteatro, com } \\
\text { powerpoint: máquinas térmicas. }\end{array}$ & $\begin{array}{l}\text { Aula suspensa: semana de } \\
\text { olimpíadas na escola. }\end{array}$ & $\begin{array}{l}\text { Aula suspensa: paralisação dos } \\
\text { professores. }\end{array}$ \\
\hline
\end{tabular}


Quadro 2. continuação

\begin{tabular}{|c|c|c|c|}
\hline \multicolumn{4}{|c|}{$\begin{array}{l}\text { Principais ações/atividades dos professores de Física } \\
\text { observados nos estudos de caso III, IV e V (descritos no item 2) }\end{array}$} \\
\hline & Estudo III (escola particular) & Estudo IV (escola militar) & Estudo V (escola pública) \\
\hline A11 & $\begin{array}{l}\text { Esclarecimento de dúvidas; } \\
\text { exposição livre de ideias } \\
\text { sobre máquinas térmicas do } \\
\text { quotidiano; solicitação de } \\
\text { material p/construção de câmara } \\
\text { escura. }\end{array}$ & $\begin{array}{l}\text { Aula suspensa: semana de } \\
\text { olimpíadas na escola. }\end{array}$ & $\begin{array}{l}\text { Aula suspensa: paralisação dos } \\
\text { professores. }\end{array}$ \\
\hline A12 & $\begin{array}{l}\text { Condução da observação } \\
\text { nos grupos: câmara escura } \\
\text { (construída pelos alunos) como } \\
\text { organizador prévio para Óptica } \\
\text { Geométrica. }\end{array}$ & $\begin{array}{l}\text { Aula suspensa: semana de } \\
\text { olimpíadas na escola. }\end{array}$ & $\begin{array}{l}\text { Aula deveria ocorrer no } 4^{\circ} \\
\text { período; antecipação para o } \\
3^{\circ} \text { por falta de professor nesse } \\
\text { período; envio de lista de } \\
\text { exercícios em substituição à } \\
\text { prova pelo docente de Física, } \\
\text { que atendia outra turma. }\end{array}$ \\
\hline A13 & $\begin{array}{l}\text { Professor ausentou-se da sala } \\
\text { para prestar socorro a uma } \\
\text { aluna. Combinou discussões } \\
\text { para aula seguinte. }\end{array}$ & Feriado. & $\begin{array}{l}\text { Finalização da resolução da lista } \\
\text { de exercícios substitutiva da } \\
\text { prova, tarefa em grupo. }\end{array}$ \\
\hline A14 & $\begin{array}{l}\text { Incitada a livre colocação de } \\
\text { ideias buscando explicar o } \\
\text { observado na câmara escura. }\end{array}$ & Feriado. & $\begin{array}{l}\text { Continuação da resolução da } \\
\text { lista de exercícios substitutiva } \\
\text { da prova, tarefa colaborativa em } \\
\text { pequenos grupos. }\end{array}$ \\
\hline A15 & $\begin{array}{l}\text { Debate em grande grupo: } \\
\text { colocação e discussão de ideias } \\
\text { para obtenção dos princípios da } \\
\text { Óptica Geométrica. }\end{array}$ & $\begin{array}{l}\text { Teórica: leis da Termodinâmica; } \\
\text { fórmulas, gráficos e } \\
\text { exemplificações. }\end{array}$ & $\begin{array}{l}\text { Correção da lista substitutiva da } \\
\text { prova, identificação e discussão } \\
\text { refletida de erros mais comuns, } \\
\text { como revisão de conteúdo. }\end{array}$ \\
\hline A16 & $\begin{array}{l}\text { Aula suspensa: semana de } \\
\text { gincana na escola. }\end{array}$ & $\begin{array}{l}\text { Teórica: transformações } \\
\text { termodinâmicas e } \\
\text { esclarecimento de dúvidas. }\end{array}$ & $\begin{array}{l}\text { Aula suspensa: conselho de } \\
\text { classe. }\end{array}$ \\
\hline A17 & $\begin{array}{l}\text { Aula suspensa: semana de } \\
\text { gincana na escola. }\end{array}$ & $\begin{array}{l}\text { Resolução de exercícios e } \\
\text { aplicação da Avaliação Parcial } \\
\text { (AP). }\end{array}$ & $\begin{array}{l}\text { Aula suspensa: conselho de } \\
\text { classe. }\end{array}$ \\
\hline A18 & $\begin{array}{l}\text { Aula suspensa: semana de } \\
\text { gincana na escola. }\end{array}$ & $\begin{array}{l}\text { Teórica: máquinas térmicas; } \\
\text { resolução de exercícios } \\
\text { conceituais do livro; pequenos } \\
\text { debates. }\end{array}$ & $\begin{array}{l}\text { Aula deveria ocorrer em período } \\
\text { anterior; antecipação por falta } \\
\text { de professor nesse período; } \\
\text { devolução de prova e trabalhos } \\
\text { corrigidos pelo docente de } \\
\text { Física, que se fez presente em } \\
\text { parte da aula. }\end{array}$ \\
\hline A19 & $\begin{array}{l}\text { Retomado o debate de ideias e } \\
\text { elencadas algumas de consenso } \\
\text { como princípios da Óptica. }\end{array}$ & $\begin{array}{l}\text { Revisão de princípios e } \\
\text { fórmulas da Termodinâmica e } \\
\text { comentários de exercícios. }\end{array}$ & $\begin{array}{l}\text { Resolução de exercícios e } \\
\text { esclarecimento de dúvidas. }\end{array}$ \\
\hline
\end{tabular}


Quadro 2. continuação

\begin{tabular}{|c|c|c|c|}
\hline \multicolumn{4}{|c|}{$\begin{array}{l}\text { Principais ações/atividades dos professores de Física } \\
\text { observados nos estudos de caso III, IV e V (descritos no item 2) }\end{array}$} \\
\hline & Estudo III (escola particular) & Estudo IV (escola militar) & Estudo V (escola pública) \\
\hline A20 & $\begin{array}{l}\text { Estímulo ao debate de grande } \\
\text { grupo (em círculo) e negociação } \\
\text { de ideias objetivando chegar aos } \\
\text { princípios da Óptica Geométrica. }\end{array}$ & $\begin{array}{l}\text { Aplicação da Avaliação Parcial } \\
\text { (AP) }\end{array}$ & $\begin{array}{l}\text { Teórica: resistência elétrica; } \\
\text { explicação interativa: queria } \\
\text { ouvir como os alunos pensavam. }\end{array}$ \\
\hline A21 & $\begin{array}{l}\text { Seguimento aos debates de } \\
\text { grande grupo: propagação, } \\
\text { reflexão e refração da luz etc. }\end{array}$ & $\begin{array}{l}\text { Teórica: Ciclo de Carnot; } \\
\text { resolução de exercícios }\end{array}$ & $\begin{array}{l}\text { Aula deveria ocorrer no } 4^{\circ} \\
\text { período; houve antecipação para } \\
\text { o } 3^{\circ} \text { por falta de professor nesse } \\
\text { período; envio de exercícios aos } \\
\text { alunos pelo docente de Física, } \\
\text { que lecionava em outra turma. }\end{array}$ \\
\hline A22 & $\begin{array}{l}\text { Teórica com demonstração } \\
\text { simples: fenômenos ópticos. }\end{array}$ & $\begin{array}{l}\text { Demonstrações, no laboratório, } \\
\text { de instrumentos e fenômenos } \\
\text { ópticos como introdução à } \\
\text { Óptica. }\end{array}$ & $\begin{array}{l}\text { Monitoramento da conclusão da } \\
\text { lista de exercícios para serem } \\
\text { entregues. }\end{array}$ \\
\hline A23 & $\begin{array}{l}\text { Resolução de exercícios; } \\
\text { negociação de ideias e } \\
\text { esclarecimento de dúvidas. }\end{array}$ & $\begin{array}{l}\text { Demonstrações, no laboratório, } \\
\text { de instrumentos e fenômenos } \\
\text { ópticos como introdução à } \\
\text { Óptica. }\end{array}$ & $\begin{array}{l}\text { Teórica: Lei de Ohm; } \\
\text { apresentação de resumo escrito } \\
\text { no quadro. }\end{array}$ \\
\hline A24 & $\begin{array}{l}\text { Aula suspensa: conselho de } \\
\text { classe na escola. }\end{array}$ & $\begin{array}{l}\text { Teórica com pequenas } \\
\text { discussões das demonstrações: } \\
\text { luz, comportamento dual da luz, } \\
\text { espectro, fenômenos ópticos. }\end{array}$ & $\begin{array}{l}\text { Aula suspensa: paralisação dos } \\
\text { professores. }\end{array}$ \\
\hline A25 & $\begin{array}{l}\text { Teórica: imagens no espelho } \\
\text { plano, explicou o observado na } \\
\text { câmara escura. }\end{array}$ & $\begin{array}{l}\text { Teórica: imagens no espelho } \\
\text { plano; resolução exercícios do } \\
\text { livro de texto. }\end{array}$ & $\begin{array}{l}\text { Revisão do conteúdo para a } \\
\text { prova. }\end{array}$ \\
\hline A26 & $\begin{array}{l}\text { Aula suspensa: atividade } \\
\text { religiosa }\end{array}$ & $\begin{array}{l}\text { Trabalho em duplas: cinco } \\
\text { questões sobre espelhos } \\
\text { esféricos. }\end{array}$ & Aplicação de prova. \\
\hline A27 & Aplicação de prova. & $\begin{array}{l}\text { Teórica: espelhos esféricos, } \\
\text { definição e construção de } \\
\text { imagens. }\end{array}$ & Aplicação de prova. \\
\hline A28 & $\begin{array}{l}\text { Teórica: espelhos planos. } \\
\text { Incitadas pequenas discussões } \\
\text { para que os alunos falassem } \\
\text { como pensavam. }\end{array}$ & $\begin{array}{l}\text { Teórica: espelhos esféricos, } \\
\text { construção de imagens, } \\
\text { principais raios. }\end{array}$ & $\begin{array}{l}\text { Correção da prova como revisão } \\
\text { e esclarecimento de dúvidas. }\end{array}$ \\
\hline A29 & $\begin{array}{l}\text { Teórica: formação de imagens } \\
\text { em espelhos planos. }\end{array}$ & $\begin{array}{l}\text { Resolução de exercícios pelos } \\
\text { alunos, atividade mediada pelo } \\
\text { docente. }\end{array}$ & $\begin{array}{l}\text { Continuação da correção } \\
\text { da prova como revisão e } \\
\text { esclarecimento de dúvidas. }\end{array}$ \\
\hline A30 & $\begin{array}{l}\text { Teórica: imagens em espelhos } \\
\text { planos, reflexão da luz. Aula } \\
\text { tumultuada, sem muitos } \\
\text { avanços. }\end{array}$ & $\begin{array}{l}\text { Revisão para Avaliação } \\
\text { Parcial sobre Termodinâmica } \\
\text { através de quatro exercícios } \\
\text { representativos. }\end{array}$ & $\begin{array}{l}\text { Revisão: corrente, resistência } \\
\text { elétrica e Lei de Ohm; } \\
\text { proposição de exercícios. }\end{array}$ \\
\hline
\end{tabular}


Quadro 2. continuação

\begin{tabular}{|c|c|c|c|}
\hline \multicolumn{4}{|c|}{$\begin{array}{l}\text { Principais ações/atividades dos professores de Física } \\
\text { observados nos estudos de caso III, IV e V (descritos no item 2) }\end{array}$} \\
\hline & Estudo III (escola particular) & Estudo IV (escola militar) & Estudo V (escola pública) \\
\hline A31 & $\begin{array}{l}\text { Resolução de exercícios da } \\
\text { apostila. }\end{array}$ & $\begin{array}{l}\text { Teórica: reflexão e refração da } \\
\text { luz e exercícios conduzidos pelo } \\
\text { docente. }\end{array}$ & $\begin{array}{l}\text { Aula suspensa: passeio da } \\
\text { turma com docente de outra } \\
\text { disciplina. }\end{array}$ \\
\hline A32 & $\begin{array}{l}\text { Estimulada a resolução } \\
\text { de exercícios em grupo c/ } \\
\text { discussões. }\end{array}$ & $\begin{array}{l}\text { Aplicação de Avaliação Parcial } \\
\text { (AP). }\end{array}$ & $\begin{array}{l}\text { Resumo escrito e exercícios } \\
\text { (Lei Ohm). }\end{array}$ \\
\hline A33 & $\begin{array}{l}\text { Teórica: espelhos esféricos, } \\
\text { pequena demonstração. }\end{array}$ & $\begin{array}{l}\text { Fenômenos ópticos, aula } \\
\text { marcada por perguntas e } \\
\text { pequenas discussões. }\end{array}$ & $\begin{array}{l}\text { Teórica: associação de } \\
\text { resistores; pequenas discussões } \\
\text { e exercícios formulados } \\
\text { como desafio, com situações } \\
\text { associadas ao cotidiano. }\end{array}$ \\
\hline A34 & $\begin{array}{l}\text { Teórica: formação de imagens } \\
\text { espelhos esféricos (ritmo mais } \\
\text { acelerado com o intuito de } \\
\text { avançar no conteúdo). }\end{array}$ & $\begin{array}{l}\text { Revisão para a prova bimestral: } \\
\text { Termodinâmica; alguns alunos } \\
\text { puderam fazer a AP que não } \\
\text { tinham feito. }\end{array}$ & $\begin{array}{l}\text { Resolução dos exercícios } \\
\text { conduzida pelo docente sobre } \\
\text { associação de resistores. }\end{array}$ \\
\hline A35 & $\begin{array}{l}\text { Teórica: imagens em espelhos } \\
\text { esféricos (ritmo mais acelerado); } \\
\text { resolução de exercícios em } \\
\text { conjunto com os alunos. }\end{array}$ & $\begin{array}{l}\text { Revisão: curiosidades de } \\
\text { aspectos do cotidiano, } \\
\text { esclarecimentos, alguma } \\
\text { descontração e troca de ideias. }\end{array}$ & $\begin{array}{l}\text { Conclusão da resolução } \\
\text { de exercícios; incentivo à } \\
\text { participação dos alunos, troca } \\
\text { de ideias. }\end{array}$ \\
\hline A36 & $\begin{array}{l}\text { Aula de exercícios e } \\
\text { esclarecimento de dúvidas. }\end{array}$ & $\begin{array}{l}\text { Alunos responderam } \\
\text { questionário sobre concepções } \\
\text { epistemológicas e prova } \\
\text { bimestral. }\end{array}$ & $\begin{array}{l}\text { Teórica: associação de } \\
\text { resistores em paralelo; } \\
\text { proposição de exercícios para } \\
\text { os alunos resolverem. }\end{array}$ \\
\hline A37 & $\begin{array}{l}\text { Apresentação oral dos trabalhos } \\
\text { de grupo e discussão de ideias: } \\
\text { projeto de pesquisa "luz e cor". }\end{array}$ & Prova bimestral. & $\begin{array}{l}\text { Aula suspensa: greve dos } \\
\text { professores. }\end{array}$ \\
\hline
\end{tabular}

Fonte: Elaborado pelos autores.

O Prof. A (Estudo III) foi quem desenvolveu o maior número de estratégias inovadoras: iniciou a Óptica Geométrica por meio da construção e observação da câmara escura nos grupos e propiciou uma sequência de debates abertos para que, por intermédio da socialização de ideias, os alunos chegassem aos princípios da Óptica Geométrica; fez pequenas demonstrações com objetos simples, transformou a resolução de exercícios em oportunidades de ouvir, dos alunos, suas explicações dos fenômenos e, com isso, permitiu, em muitos momentos, a discussão de outros assuntos pertinentes e motivadores. Foi perceptível um esforço para diversificar suas estratégias e problematizar os conteúdos estudados. Mas essas oportunidades nem sempre eram bem aproveitadas, pois os alunos se mostravam dispersivos e pareciam mais dispostos a receber o conhecimento pronto, como ocorre de costume. Além disso, com frequência, a má condução resultava em perda de foco das discussões (retomaremos esse aspecto mais adiante). 
Uma análise cruzada de três estudos de caso...

Tabela 1. Categorização das estratégias didáticas dos professores (A, B e C) a partir do Quadro 2

\begin{tabular}{|c|c|c|c|c|c|}
\hline & $\begin{array}{c}\text { Estratégia } \\
\text { diversificada }\end{array}$ & $\begin{array}{l}\text { Estratégia } \\
\text { inovadora }\end{array}$ & $\begin{array}{l}\text { Estratégia } \\
\text { tradicional }\end{array}$ & Aula suspensa & $\begin{array}{c}\text { Total de } \\
\text { horas-aula }\end{array}$ \\
\hline Prof. A & $\begin{array}{c}9 \\
(\mathrm{~A} 2 ; \mathrm{A} 3 ; \mathrm{A} 5 ; \mathrm{A} 21 ; \\
\text { A22; } \\
\text { A23; A32; A33; } \\
\text { A37) }\end{array}$ & $\begin{array}{c}\mathbf{8} \\
\text { (A10; } 11 ; \mathrm{A} 12 ; \\
\text { A14; A15; } 19 ; \\
\text { A20; A28) }\end{array}$ & $\begin{array}{c}14 \\
(\mathrm{~A} 1 ; \mathrm{A} 4 ; \mathrm{A} 6 ; \mathrm{A} 7 ; \mathrm{A} 8 ; \mathrm{A} 9 \\
\mathrm{A} 25 ; \mathrm{A} 27 ; \mathrm{A} 29 ; \mathrm{A} 30 \\
\mathrm{~A} 31 ; \mathrm{A} 34 ; \mathrm{A} 35 ; \mathrm{A} 36)\end{array}$ & $\begin{array}{c}\mathbf{6} \\
(\mathrm{A} 13 ; \mathrm{A} 16 ; \mathrm{A} 17 ; \\
\mathrm{A} 18 ; \mathrm{A} 24 ; \mathrm{A} 26)\end{array}$ & 37 \\
\hline Prof. B & $\begin{array}{c}\mathbf{4} \\
(\mathrm{A} 15 ; \mathrm{A} 18 ; \mathrm{A} 26 \\
\mathrm{A} 33)\end{array}$ & $\begin{array}{c}\mathbf{4} \\
(\mathrm{A} 22 ; \mathrm{A} 23 ; \mathrm{A} 24 ; \\
\mathrm{A} 35)\end{array}$ & $\begin{array}{c}22 \\
(\mathrm{~A} 1 ; \mathrm{A} 2 ; \mathrm{A} 3 ; \mathrm{A} 4 ; \mathrm{A} 5 ; \\
\text { A6; A7; A16; A17; A19; } \\
\text { A20; A21; A25; A27; } \\
\text { A28; A29; A30; A31; } \\
\text { A32; A34; A36; A37) }\end{array}$ & $\begin{array}{c}7 \\
(\mathrm{~A} 8 ; \mathrm{A} 9 ; \mathrm{A} 10 ; \mathrm{A} 11 ; \\
\text { A12; A13; A14) }\end{array}$ & 37 \\
\hline Prof. C & $\begin{array}{c}7 \\
(\mathrm{~A} 1 ; \mathrm{A} 2 ; \mathrm{A} 3 ; \mathrm{A} 9 \\
\mathrm{A} 14 ; \\
\mathrm{A} 15 ; \mathrm{A} 35)\end{array}$ & $\begin{array}{c}\mathbf{5} \\
(\mathrm{A} 5 ; \mathrm{A} 7 ; \mathrm{A} 8 ; \mathrm{A} 20 ; \\
\mathrm{A} 33)\end{array}$ & $\begin{array}{c}14 \\
\text { (A4; A13; A19; A22; } \\
\text { A23; A25; } \\
\text { A26; A27; A28; A29; } \\
\text { A30; A32; } \\
\text { A34; A36) }\end{array}$ & $\begin{array}{c}11 \\
\text { (A6; A10; A11; } \\
\text { A12; A16; A17; } \\
\text { A18; A21; A24; } \\
\text { A31; A37) }\end{array}$ & 37 \\
\hline
\end{tabular}

Fonte: Elaborado pelos autores.

O Prof. C (Estudo V) também desenvolveu esforços para diversificar suas estratégias, fez pequenas demonstrações e tentou envolver os estudantes na resolução exaustiva de exercícios buscando abordar situações práticas; incitou discussões pontuais no sentido de captar a atenção dos alunos para associar a Física ao cotidiano e, com frequência, chamou a atenção dos alunos de que "estamos vendo um modelo científico, não a realidade". Todavia, foi no ambiente da escola pública onde se observou o maior número de aulas suspensas (aulas desperdiçadas, períodos antecipados para o imediatamente anterior por falta de professor em outra disciplina, em que o docente de Física não podia estar presente, pois atendia a outra turma, paralisações, greves e outros eventos) e em que os problemas de contexto, como a falta de organização escolar, a indisciplina dos alunos, se fizeram sentir de forma mais contundente.

Com base nesses dados e procurando estabelecer relações entre as visões epistemológicas dos professores observados e suas estratégias didáticas, construiu-se, tentativamente, o Quadro 3.

O exame do Quadro 3 sugere que há um predomínio de estratégias tradicionais na atuação dos professores de Física em sala de aula no Ensino Médio, com aulas expositivas e resolução de exercícios.

É possível perceber que o professor que apresentou concepções superadas sobre a natureza da ciência, que aqui foram denominadas empírico-indutivistas, foi quem privilegiou estratégias didáticas tradicionais; transmitiu o conhecimento sem oferecer espaço ao debate; apresentou o conteúdo seguindo, com rigor, o livro didático; conduziu com precisão e objetividade a resolução de exercícios, incentivando a aquisição de habilidades matemáticas e manejo com as fórmulas. O rigor e objetividade são, em certo sentido, características didáticas desejáveis, mas o tratamento excessivamente formal dos conteúdos distancia a Física do cotidiano dos alunos e não incita a inquietação indagadora, a reflexão e a criticidade. 
Quadro 3. Concepções epistemológicas dos professores versus estratégias didáticas

\begin{tabular}{|l|l|l|}
\hline $\begin{array}{l}\text { Professor } \\
\text { observado }\end{array}$ & \multicolumn{1}{|c|}{$\begin{array}{c}\text { Concepções epistemológicas } \\
\text { dos professores }\end{array}$} & \multicolumn{1}{|c|}{$\begin{array}{c}\text { Estratégias didáticas mais utilizadas } \\
\text { no período de observação }\end{array}$} \\
\hline Prof. A & $\begin{array}{l}\text { Alinhadas às visões epistemológicas } \\
\text { contemporâneas }\end{array}$ & $\begin{array}{l}\text { Estratégias tradicionais em várias aulas, mas, } \\
\text { comparativamente, utilizou o maior número de } \\
\text { estratégias didáticas inovadoras e diversificadas. }\end{array}$ \\
\hline Prof. B & $\begin{array}{l}\text { Empírico-indutivistas ou não } \\
\text { alinhadas às visões contemporâneas } \\
\text { da natureza da ciência }\end{array}$ & $\begin{array}{l}\text { Utilizou, preferencialmente, estratégias tradicionais de } \\
\text { ensino. }\end{array}$ \\
\hline Prof. C & $\begin{array}{l}\text { Pelo menos, parcialmente } \\
\text { alinhadas às visões epistemológicas } \\
\text { contemporâneas }\end{array}$ & $\begin{array}{l}\text { Estratégias tradicionais em várias aulas, mas } \\
\text { procurou diversificar suas estratégias didáticas e, } \\
\text { especialmente, buscou discutir aspectos da Física } \\
\text { associados ao cotidiano. }\end{array}$ \\
\hline
\end{tabular}

Fonte: Elaborado pelos autores.

Este professor passou, de forma implícita, uma ideia de que a ciência, e em especial a Física, constrói um conhecimento inquestionável e imutável, em que racionalidade se traduz em coerência lógica. A imersão em sala de aula e os dados aqui categorizados induzem a esta interpretação, embora, na entrevista, o Prof. B tenha informado deter visões menos conservadoras e se disse consciente de que esse tipo de ensino não prepara para a cidadania, mas se volta para o vestibular e busca atender ao projeto pedagógico da escola militar, bastante conteudista. Esse contexto, é bem verdade, acabava influenciando nas práticas didáticas, mas a longa trajetória docente do Prof. B na escola militar e em curso de engenharia de uma grande universidade pareciam marcar fortemente suas crenças de que "a Física é assim porque é assim". Em suma, o Prof. B foi, dentre os professores observados, o que menos inovou em suas estratégias didáticas, procurou manter, em aula, uma postura rigorosa, pouco flexível, e passou uma imagem de que o conhecimento científico está alicerçado em leis e teorias fixas e imutáveis, oriundas do uso rigoroso do "método científico".

De outro lado, os dois outros docentes (Prof. A e Prof. C) ofereceram indícios de que veem a ciência como uma construção humana; que entendem as leis como explicações da natureza por meio de modelos; concebem o conhecimento científico como falível, provisório e testável por diferentes metodologias; e se mostraram mais abertos, mais dispostos a testar novas estratégias didáticas, a se expor ao erro, a refletir sobre suas práticas e a questionar o próprio sistema educativo no qual estão imersos.

Destaca-se, novamente, que não é possível generalizar esses achados porque a descrição etnográfica indicou que o contexto em que ocorrem os eventos educativos, o tipo de escola e seus objetivos, a personalidade do professor e o entrosamento com os alunos têm grande influência sobre o tipo de prática didática que ele adota.

Por exemplo, no Estudo IV, o Prof. B era, em grande parte, incentivado pela escola a conduzir, com rigor metódico e disciplinar, as suas aulas, com o objetivo de cumprir rigorosamente um extenso programa de ensino. De igual forma, o Prof. C, Estudo V, teve a interferência de inúmeras variáveis externas à sala de aula e à própria escola, situações comuns ao sistema público de ensino, impondo-lhe severas dificuldades, que tiveram importante interferência nas suas decisões em sala de aula. 
Como foi visto anteriormente, existe um consenso geral, na literatura em educação científica, em torno do objetivo de melhorar a visão sobre a natureza da ciência de professores e estudantes, e um extenso corpo de investigação alerta para a eficácia de abordagens instrucionais explícitas para melhorar a aprendizagem da natureza da ciência. Sugerem esses estudos que o envolvimento dos alunos na argumentação pode ajudar a desenvolver seus pontos de vista e levá-los a reflexões críticas. McDonald (2010) informa que uma análise crítica da eficácia de um curso de conteúdo científico para professores, com estratégias explícitas sobre a natureza da ciência, permitiu identificar três fatores que mediaram uma melhoria de suas visões durante a intervenção: (a) fatores contextuais (contexto e modo de argumentação); (b) fatores relacionados a tarefas específicas (diferentes visões epistemológicas, a consideração de dados e explicações alternativas); e (c) fatores pessoais (conhecimento prévio, valorização da importância e utilidade da natureza da ciência, persistência das crenças preexistentes).

O que nossa investigação parece indicar, especialmente o ordenamento que resultou na Tabela 1 e no Quadro 3, é que os professores que têm visões epistemológicas mais alinhadas às visões contemporâneas (Prof. A e Prof. C) têm maior tendência para diversificar suas estratégias didáticas; dispõem-se, frequentemente, ao debate de grande grupo, à negociação de ideias sobre os fenômenos físicos em estudo; propõem-se a ouvir as formas de explicação dos alunos e, com isso, identificam, não raro, concepções alternativas às explicações aceitas cientificamente; aceitam a controvérsia; negociam significados; afirmam com mais naturalidade que não sabem responder quando questionados sobre aspectos que não dominam; prontificam-se a pesquisar e trazer respostas; não passam uma ideia de que o professor tudo sabe. Ressalta-se, uma vez mais, que muito do que obtivemos como "achados" deste estudo, sem dúvida, resultou de vivências em interação com os professores e alunos ao longo das observações participantes, ricas oportunidades de aprendizado, de troca de impressões, experiências que, certamente, levaremos para a vida. Experiências descritas e interpretadas qualitativamente com objetividade, tanto quanto possível, porque um dos objetivos fundamentais de uma análise qualitativa de boa qualidade é manter o equilíbrio entre a objetividade e a sensibilidade, esta última, necessária para perceber as nuanças e significados dos dados, mas não quantificáveis.

Percebeu-se que os professores que detêm visões mais contemporâneas sobre a natureza da ciência mostram-se mais abertos e flexíveis às mudanças, mas demonstram dificuldades para gerir suas próprias concepções (sobre o papel e origem das leis e teorias) e quando abordam essas questões o fazem de forma confusa e invariavelmente implícita. Mostram-se, assim, despreparados para fazer argumentações explícitas para esclarecer a origem e as controvérsias dos conceitos físicos, das leis e teorias. Não raro perdem o foco em sala de aula, promovendo discussões e debates inacabados, mal conduzidos e que, em vários momentos, acabam por gerar um clima de ansiedade nos alunos ao invés de procurar encaixar os princípios científicos que dão solução a perguntas cotidianas e tentar esclarecer quão humana é a ciência.

Com isso, passam uma ideia muito tênue, quase imperceptível, sobre a importância que eles próprios atribuem aos aspectos relacionados à natureza da ciência. Não conseguem operacionalizar, diferentemente do que expressaram nas entrevistas (MASSONI, 2010), uma abordagem da Física que também inclua algo sobre a Física. Demonstram que as relações entre o discurso de sala de aula e as visões contemporâneas sobre a natureza e evolução da ciência são frágeis: resumem-se a tentativas tímidas, implícitas e pouco eficazes. Pode-se dizer que, dessa forma, as "visões epistemológicas contemporâneas", tão bem discutidas na literatura, não chegam à sala de aula do Ensino Médio. 
As tentativas implícitas e desarticuladas revelam que este é um processo incipiente e incapaz de gerar mudanças nas visões sobre a natureza da ciência dos alunos, ou de se traduzir em aumento da motivação para que estudem mais e melhor a Física ensinada.

Contudo, há que se atentar para a importância da diversidade observada nas distintas escolas. A diversidade, ao que parece, depende de combinações peculiares de vários fatores: condições físicas (prédios, instalações, tamanho e adequação das salas de aula, limpeza etc.), disciplina, ambiente e nível de relacionamento entre alunos, entre professores e alunos, entre alunos e direção, organização e definição de objetivos gerais (da escola) e específicos (da disciplina), e resulta em distintos níveis de interesse de professores e alunos, de expectativas dos estudantes em relação ao ensino que lhes é oferecido e ao que fazem ou deveriam fazer os professores, de rendimento e expectativas de rendimento em testes de Física e, também, em distintas posturas dos professores.

Isto sugere que a implementação de mudanças nas práticas docentes não é um processo simples, nem fácil. O mais comum é darem-se mudanças secundárias, como as hipóteses auxiliares de Lakatos (1993), mantendo-se o núcleo firme, que parece ser: os professores ensinam, em geral, como eles próprios foram ensinados. Se nossa expectativa era observar práticas docentes visivelmente distintas e melhores, daqueles professores que detêm visões contemporâneas sobre a natureza da ciência, não foi o que observamos. Parece que as formas de raciocínio, o discurso e as estratégias adotadas no ensino de Física não sofreram influências diretas das "visões epistemológicas contemporâneas", mesmo quando não nos restavam dúvidas de que as concepções do professor eram a elas alinhadas.

Essa assertiva parece estar grandemente baseada na constatação de que as diferentes escolas, com suas diferentes perspectivas, estavam atreladas a uma mesma estrutura básica: ensinava-se uma Física Clássica apresentando seus principais conceitos, leis e teorias, preferencialmente por meio de fórmulas, ou expressões matemáticas que relacionam os conceitos principais, e, depois, adotava-se outra perspectiva e procuravam-se desenvolver habilidades para manipular as fórmulas por intermédio de exaustiva resolução de exercícios, na esperança de que os conceitos e teorias adquirissem significado para os alunos.

Não é fácil, contudo, responder "por que" se observam essas tendências. Há, ao que parece, uma relação psicológica que conduz naturalmente o professor a agarrar-se à "infraestrutura tácita de ideias” (BOHM, 1988, p. 39, tradução nossa) bem estabelecidas, seguras, que funcionaram na sua própria educação escolar. Bohm (1988) advertiu que essa adesão bloqueia a criatividade e que a mente do cientista - e por que não do professor de ciências -, deve estar sempre alerta a novas percepções. Também é possível perceber no cotidiano dos eventos educativos que "o ato de ensinar" inclui elementos advindos da prática, como a improvisação, a experimentação na prática didática. Por outro lado, a sala de aula é um espaço conflituoso, em que ideias, interesses e concepções divergentes se confrontam; e, para lidar com essa situação, o professor precisa estar bem preparado. Nesse sentido, esforço e investimento na preparação de professores de qualidade adquire grande importância. 


\section{Considerações finais}

Ainda que com fracas evidências, o cruzamento dos casos sugere que aqueles docentes que detêm concepções mais atuais, mais flexíveis sobre a natureza da ciência, possivelmente transformadas por influência de disciplinas de Epistemologia, ou similares, por seus históricos acadêmicos, adotam consciente, e, às vezes, inconscientemente, estratégias didáticas diferenciadas com a mesma abertura de espírito, flexibilidade e predisposição para o desconhecido como concebem o processo da ciência em si.

Esta se mostrou uma importante relação entre as concepções epistemológicas contemporâneas e as estratégias didáticas dos professores que as detêm: a assunção de um espírito aberto à discussão, à mudança, à inovação, ao desafio da indagação reflexiva.

Se esses professores criaram algumas oportunidades de ensinar uma Física "como ela é", fizeram crer que: 1) o homem não ensina sobre aquilo em que ele próprio não crế; 2) razão pela qual é tão importante investir na formação inicial e continuada dos professores, buscando transformar suas concepções sobre a natureza da ciência, com vistas a adotarem estratégias mais flexíveis, diversificadas e a tornarem-se mais críticos e reflexivos.

Ao que parece, essa é a mais importante contribuição que as "visões epistemológicas contemporâneas" podem oferecer para a melhoria do ensino de Física. Embora a questão da mudança epistemológica se mostre um processo incipiente, desarticulado e com muitas questões em aberto, a esperança reside no fato de que a mudança mais profunda começa com as pessoas, e, se o professor tem arraigada convicção para a mudança, ela acontece, lenta e com pequenas atitudes que, inevitavelmente, se irradiam para o macrossistema.

\section{Referências}

ASTOLFI, J. P.; DEVELAY, M. A didática das ciências. 12. ed. Campinas: Papirus, 2008.

BACHELARD, G. A filosofia do não. Lisboa: Presença, 1988.

BELL, R. L.; LEDERMAN, N. G.; ABD-EL-KHALICK, F. Implicit versus explicit nature of science instruction: an explicit response to Palmquist and Finley. Journal of Research in Science Teaching, Hoboken, v. 35, n. 9, p. 1057-1061, 1998.

BEVILACQUA, F.; GIANNETTO, E. The history of physics and European physics education.

Science \& Education, Dordrecht, v. 5, n. 3, p. 235-246, 1996.

BLANTON, P. Constructing knowledge. The Physics Teacher, College Park, v. 41, n. 2, p. 125-126, 2003.

BOGDAN, R. C.; BIKLEN, S. K. Investigação qualitativa em educação. Porto: Porto Editora, 1994.

BOHM, D.; PEAT, F.D. Ciencia, orden y creatividad. 2. ed. Barcelona: Kairós, 1998.

BRAKE, M.; HOOK, N. Science, fiction and the age of discovery. Physics Education, Bristol, v. 42, n. 3, p. 245-252, 2007. 
BRASIL. Ministério da Educação e Cultura. Orientações curriculares para o ensino médio: ciências da natureza, matemática e suas tecnologias. Brasília: Secretaria de Educação Básica, 2006. v. 2.

EL-HANI, C. N.; TAVARES, E. J. M.; ROCHA, P. L. B. Concepções epistemológicas de estudantes de biologia e sua transformação por uma proposta explícita de ensino sobre história e filosofia das ciências. Investigações em Ensino de Ciências, Porto Alegre, v. 9, n. 3, p. 365-313, 2004.

ESPINOZA, F. An analysis of the historical development of ideas about motion and its implications for teaching. Physics Education, Bristol, v. 40, n. 2, p. 139-146, 2005.

HARRES, J. B. S. Uma revisão de pesquisas nas concepções de professores sobre a natureza da ciência e suas implicações para o ensino. Investigações em Ensino de Ciências, Porto Alegre, v. 4, n. 3, p. 197-211, 1999.

HASHWEH, M. Z. Effects of science teachers' epistemological beliefs in teaching. Journal of Research in Science Teaching, Hoboken, v. 33, n. 1, p. 47-63, 1996.

LAKATOS, I. Metodología de los programas de investigación científica. Madrid: Alianza, 1993.

LEDERMAN, N. G. Students' and teachers' conceptions of the nature of science: a review of the research. Journal of Research in Science Teaching, Hoboken, v. 29, n. 4, p. 331-359, 1992.

. Teachers' understanding of the nature of science and classroom practice: factors that facilitate or impede the relationship. Journal of Research in Science Teaching, Hoboken, v. 36, n. 8, p. 916-929, 1999.

MARTINS, A. F. P. História e filosofia da ciência no ensino: há muitas pedras nesse caminho.

Caderno Brasileiro de Ensino de Física, Florianópolis, v. 24, n. 1, p. 112-131, 2007.

MASÓN, N. T.; MOREIRA, M. A. Um estudo exploratório sobre a contribuição de visões epistemológicas contemporâneas na transformação das concepções de professores de física atuantes. TED: tecné, episteme y didaxis, Bogotá, n. 22, p. 5-31, 2007. Disponível em: <http://revistas. pedagogica.edu.co/index.php/TED/issue/view/44/showToc >. Acesso em: 06 jun. 2014.

MASSONI, N. T. A epistemologia contemporânea e suas contribuições em diferentes níveis de ensino de física: a questão da mudança epistemológica. $412 \mathrm{f}$. Tese (Doutorado em Ciências) Instituto de Física, Universidade Federal do Rio Grande do Sul, Porto Alegre, 2010.

MASSONI, N. T.; MOREIRA, M. A. Un enfoque epistemológico de la enseñanza de la física: una contribución para el aprendizaje significativo de la física, con muchas cuestiones sin respuesta. Revista Electrónica de Enseñanza de las Ciencias, Vigo, v. 9, n. 2, p. 283-309, 2010.

MASSONI, N. T.; MOREIRA, M. A. La enseñanza de física en una escuela militar: ¿una herencia behaviorista? REIEC: revista electrónica de investigación en educación en ciencias, Tandil, v. 6 , n. 2, p. 1-24, 2011.

MASSONI, N. T.; MOREIRA, M. A. Ensino de física em uma escola pública: um estudo de caso etnográfico com um viés epistemológico. Investigações em Ensino de Ciências, Porto Alegre, v. 17, n. 1, p. 147-181, 2012.

MATTHEWS, M. R. História, filosofia e ensino de ciências: a tendência atual de reaproximação.

Caderno Catarinense de Ensino de Física, Florianópolis, v. 12, n. 3, p. 164-214, 1995.

. Teaching the philosophical and worldview components of science. Science $\&$ Education,

Dordrecht, v. 18, n. 6-7, p. 697-728, 2009. 
Uma análise cruzada de três estudos de caso...

MATTHEWS, R. ¿Por qué la araña no se queda pegada a la tela? y otros mistérios mundanos de la ciencia. Barcelona: Ariel, 2010.

McDONALD, C.V. The influence of explicit nature of science and argumentation instruction on preservice primary teachers' views of nature of science. Journal of Research in Science Teaching, Hoboken, v. 47, n. 9, p. 1137-1164, 2010.

MEICHTRY, Y. J. The impact of science curricula on students views about the nature of science. Journal of Research in Science Teaching, Hoboken, v. 30, n. 5, p. 429-443, 1993.

MELO, A. C. S.; PEDUZZI, L. O. Q. Contribuições da epistemologia bachelardiana no estudo da história da óptica. Ciência \& Educação, Bauru, v. 13, n. 1, p. 99-126, 2007.

MESTRE, J. P. Implications of research on learning for the education of prospective science and Physics teachers. Physics Education, Bristol, v. 36, n. 1, p. 44-51, 2001.

MOREIRA, M. A. A física dos quarks e a epistemologia. Revista Brasileira de Ensino de Física, São Paulo, v. 29, n. 2, p. 161-173, 2007.

MOREIRA, M. A.; MASSONI, N. T.; OSTERMANN, F. História e epistemologia da física na licenciatura em física: uma disciplina que busca mudar concepções dos alunos sobre a natureza da ciência. Revista Brasileira de Ensino de Física, São Paulo, v. 29, n. 1, p. 129, 2007.

MORRISON, J. A.; RAAB, F.; INGRAM, D. Factors influencing elementary and secondary teachers' views on the nature of science. Journal of Research in Science Teaching, Hoboken, v. 46, n. 4, p. 384-403, 2009.

PEME-ARANEGA et al. La interacción entre concepciones y la práctica de una profesora de Física de nivel secundario: estudio longitudinal de desarrollo profesional basado en el proceso de reflexión orientada colaborativa. Revista Electrónica de Enseñanza de las Ciencias, Vigo, v. 8, n. 1, p. 283 303, 2009. Disponível em: <http://reec.uvigo.es/volumenes/volumen8/ART15_Vol8_N1.pdf >. Acesso em: 06 jun. 2014.

PHYSICS first: an informational guide for teachers, school administrators, parents, scientists, and the public. [S.1.]: AAPT, 2006. Disponível em: <http://www.aapt.org/aboutaapt/updates/upload/ physicsfirst.pdf>. Acesso em: 05 jun. 2014.

RENN, J. A física clássica de cabeça para baixo: como Einstein descobriu a teoria da relatividade especial. Revista Brasileira de Ensino de Física, São Paulo, n. 27, n. 1, p. 27-36, 2004.

RICARDO, E. C.; CUSTÓDIO, J. F.; REZENDE JUNIOR, M. F. Comentários sobre as orientações curriculares de 2006 para o ensino de física. Revista Brasileira de Ensino de Física, São Paulo, v. 30, n. 2, p. 2401, 2008.

RYDER, J.; LEACH, J.; DRIVER, R. Undergraduate science students' images on science. Journal of Research in Science Teaching, Hoboken, v. 36, n. 2, p. 201-219, 1999.

SANDOVAL, J. S.; CUDMANI, L. C.; MADOZZO, M. J. Las concepciones epistemológicas de los docentes en la enseñanza de las ciencias fácticas. Revista Brasileira de Ensino de Física, São Paulo, v. 17, n. 1, p. 550-61, 1995.

SAWYER, R. D. Situating teacher development: the view from two teachers' perspectives. International Journal of Educational Research, Hoboken, v. 37, n. 8, p. 733-753, 2002. 
SILVA, C.C.; MOURA, B. A. A natureza da ciência por meio do estudo de episódios históricos: o caso da popularização da óptica newtoniana. Revista Brasileira de Ensino de Física, São Paulo, v. 30, n. 1, p. 1602, 2008.

SOLOMON, J.; DUVEEN, J.; SCOT, L. Teaching about the nature of science through history: action research in the classroom. Journal of Research in Science Teaching, Hoboken, v. 29, n. 4, p. 409-421, 1992.

STRAUSS, A.; CORBIN, J. Pesquisa qualitativa: técnicas e procedimentos para o desenvolvimento de teoria fundamentada. 2. ed. Porto Alegre: Artmed, 2008. 